\title{
Candidate Performance On The Business Environment And Concepts Section Of The CPA Exam
}

\author{
D.H. Lindsay, California State University, Stanislaus, USA \\ K.B. Tan, California State University, Stanislaus, USA \\ Annhenrie Campbell, California State University, Stanislaus, USA
}

\begin{abstract}
This paper examines how differences in curricular design of undergraduate accounting programs influence pass rates on the Business Environment and Concepts Section of the CPA Exam. The association of the pass rate of a school's accounting graduates to the design of the schools accounting program and to other school characteristics was examined with linear regression models. Characteristics considered were semester hours in courses covered by the CPA exam section, entrance exam scores of the schools' freshmen, whether the schools were AACSB accredited and whether the schools were public or private institutions. The number of cost and managerial accounting semester hours was consistently found to be a significant determinant of success on the new section of the CPA exam.
\end{abstract}

\section{INTRODUCTION}

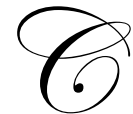

andidates for a CPA License in all United States jurisdictions -- fifty states, three territories and the District of Columbia -- are required to pass the Uniform CPA Examination. Over the years, the form and content of the CPA Exam has changed. In 2003, the exam was computerized, shortened and extensively reorganized. A new section called "Business Environment and Concepts" (BEC) was created to test candidates' mastery of topics not directly related to financial accounting. These topics, in addition to business law which had long been tested, include cost and managerial accounting, economics, finance, and information technology. The AICPA believes that as much as seventy percent of the material in this section had not previously been tested in the CPA Exam (AICPA, 2003).

The Board of Examiners has identified five specific skills that the exam addresses. These consist of analysis, judgement, communication, research, and understanding. Although the exam, in its entirety, consists of both multiple-choice questions and extensive simulations, the Business and Environment Concepts section consists only of multiple-choice questions. The examiners have determined that fifty-five to sixty-five (55 to 65) percent of this section should address the last, the "understanding" skill. This section's reliance on the remaining four skills ranges from zero to sixteen percent (Rudnick and Taylor, 2006). This paper examines how differences in curricular design of undergraduate accounting programs influence pass rates on this new section

The expansion of the breadth of exam coverage can be seen as explicit recognition by the AICPA that certified public accountants are relied upon by the public and industry for more than just audit work. Additionally, Statements of the Financial Accounting Standards Board delineating financial accounting practice increasingly rely on expertise in areas such as finance and managerial accounting. For example, Statement 131 on disaggregated financial reporting references a company's internal managerial accounting system and Statement 133 on derivatives requires an understanding of basic finance for its successful application.

The results of professional exams have often been used to examine the implications of teaching effectiveness and curricular design (Bragg, 1995; Al-Turki and Duffuaa, 2003). Disciplines other than accounting 
which generate outcomes measures from professional exams include architecture, nursing, law and various medical specialties. Of the disciplines with professional exams, accounting provides the most comprehensive reporting of pass rates with information for all jurisdictions and by candidates' school (Bragg, 1995).

Several hypotheses related to the determinants of institutional pass rates on the Business Environment and Concepts section are developed and tested in this study. The hypotheses address the influences of differences in curricular content and design found across the sampled schools. Opportunities for future research on this topic are then discussed.

\section{HYPOTHESES DEVELOPMENT}

This study uses the pass rates on the Uniform CPA Examination for the Business Environment and Concepts Section as a measurable outcome of teaching effectiveness. In addition to being objective and verifiable, the pass rate is an institutional measure. Students do not learn accounting in a single class or from a single professor but throughout an entire accounting program.

While the CPA Exam has long been used by the profession as a standardized achievement measure, it is fair to note that there have been objections to this use. Some argue that the exam does not measure the entire breadth of the curriculum and that it does not attract every graduate from a particular program (DeMong, et al., 1994). Others point out that faculty do not necessarily teach specifically for the exam (Nelson, 1995). The design of the new Business Environment and Concepts section is itself a response that broadens the topical coverage of the exam. We further argue that, if an accounting program has adequate instruction and curriculum design, its students can be expected to excel in many accounting endeavors, including candidacy for professional examinations.

On October 10, 2003, the AICPA released a working paper with "additional detail" regarding the content specification outline for the Business Environment and Concepts section of the exam that had initially been released on June 14, 2002 (AICPA, 2003). The document lists numerous study topics in five areas. The five areas in the discussion section of the document do not appear to correlate systematically with a typical college curriculum. In the conclusion to the document, however, "typical references" are listed under the headings: Business Law, Economic Concepts, Financial Management, Information Technology, and Planning and Measurement. The listed references turn out to be popular texts used in most colleges' courses in, respectively, Business Law, Economics, Finance, various Information Technology courses, and Cost and Managerial Accounting. An analysis of the five content areas of the BEC section of the exam prepared in 2003 suggested that approximately one fourth of the questions cover financial management and another fourth cover cost and managerial topics. Of the remaining three topic areas, somewhat fewer questions cover economic concepts than the remaining two (Vangermeersch and Mackey, 2003).

From the reference list provided by the AICPA, one could infer that the amount of coursework a school provides its students in each of these areas would be associated with the students' eventual pass rate on this section of the exam. This notion leads to five hypotheses:

H1: Ceteris paribus, the greater the number of required semester units of business law, the higher is a school's institutional pass rate on the Business Environment and Concepts section of the CPA Exam.

H2: Ceteris paribus, the greater the number of required semester units of economics, the higher is a school's institutional pass rate on the Business Environment and Concepts section of the CPA Exam.

H3: Ceteris paribus, the greater the number of required semester units of finance, the higher is a school's institutional pass rate on the Business Environment and Concepts section of the CPA Exam.

H4: Ceteris paribus, the greater the number of required semester units of information technology, the higher is a school's institutional pass rate on the Business Environment and Concepts section of the CPA Exam.

H5: Ceteris paribus, the greater the number of required semester units of managerial and cost accounting, the higher is a school's institutional pass rate on the Business Environment and Concepts section of the CPA Exam. 
Additional factors affecting pass rates might also be considered. It is reasonable to expect that a school's institutional pass rate will be influenced by the overall academic ability of its students. If a school attracts more academically gifted students, performance on the CPA Exam, ceteris paribus, can be expected to be stronger. Using the median ACT score of incoming freshmen to proxy for the overall academic ability of a school's students, including its business students and, therefore, its graduates, the sixth hypothesis becomes:

H6: Ceteris paribus, the greater the median ACT score of incoming freshmen, the higher is a school's institutional pass rate on the Business Environment and Concepts section of the CPA Exam.

Business schools may achieve accreditation conferred by AACSB International. The purpose of accreditation is to provide a program's stakeholders with assurances of quality. Therefore, whether a school holds accreditation is seen by many as a summary measure of program quality. It is not unreasonable to expect, therefore, that the pass rate on the CPA exam may be systematically higher for schools holding AACSB accreditation.

H7: Ceteris paribus, there is a positive association between the accreditation status of a school's business program and the school's institutional pass rate on the Business Environment and Concepts section of the CPA Exam.

Students taking the BEC section of the AICPA exam have graduated from both public and private institutions of higher education. While curricula tend to be so similar that course credit often be transferred easily between them, it has been argued that private and public institutions differ in that private institutions feel more direct pressure from parents and others to justify their higher relative costs by showing better learning outcomes measures (Geiger, 1988; Levy, 1991).

H8: Ceteris paribus, there is a positive association between the private rather than public status of a school and the school's institutional pass rate on the Business Environment and Concepts section of the CPA Exam.

\section{METHODOLOGY}

Each jurisdiction establishes its own requirements for taking the Uniform CPA Exam. Twenty-two of the jurisdictions require candidates to have completed a baccalaureate degree. The other jurisdictions require completion of a minimum of one hundred and fifty (150) post secondary semester units including those needed for the baccalaureate degree. In those jurisdictions, students need approximately a year's worth of college-level course work in addition to their four-year baccalaureate degree. In order to be sure of the relationship of the candidates to their undergraduate institutions, only the jurisdictions requiring just the baccalaureate degree, without additional semester units, were used to comprise this study's sample.

For the schools in these twenty-two jurisdictions, the pass rates of "Test Takers Without Advanced Degrees" by school for the Business Environment and Concepts section of the Uniform CPA Exam for the year 2004 were obtained from data provided by the National Association of State Boards of Accountancy (NASBA, 2005).

Most schools in the sample use the semester system rather than the quarter system. Only six schools in the sample used the quarter system. For these schools, quarter units were transformed into the equivalent semester units by multiplying by two thirds.

The undergraduate course catalog of each school was reviewed to determine which courses accounting students were required to take. No distinction was made between upper and lower division units; unit counts were determined from catalog information. It was a relatively straightforward process to count the units for business law, economics and finance courses. Any information technology course listed in the required program was counted for the information technology variable. Information technology courses were variously labeled "management information," "computer information," and "accounting information technology." Any upper or lower division managerial accounting, management accounting or cost accounting course was included for the cost accounting variable.

The variable for AACSB accreditation was given the value of "1" for accredited schools and "0" for other schools. The variable for the private or public indicator was given the value of "1" for private schools and "0" for public schools. 
Thus, six variables were continuous and two categorical. One hundred and forty-seven (147) of the schools reported their median ACT scores for incoming freshmen. The other forty-three (43) schools in the final sample of one hundred and ninety (190) reported SAT scores. Barron's Profiles of American Colleges provided this information (Barron's, 2007). To prevent loss of observations, the SAT score was converted to an ACT score for schools not reporting the median ACT score using the translation table provided by the California State University (CSU) system to determine admissions eligibility. The table for the 2005-2006 catalog year was prepared by the Chancellor's Office for mandatory inclusion in all catalogs issued by the system's twenty-three (23) campuses (CSU, Stanislaus, 2005). A multiple regression was run to test the eight hypotheses.

\section{RESULTS}

The results of the multiple regression appear in Table 1 on the following page. The model's $\mathrm{F}$ statistic is 4.081. This is significant at the 0.001 level. The $\mathrm{R}^{2}$ is 0.153 . The coefficient on the ACT variable is significant at the 0.001 level, a result consistent with hypothesis six. Clearly, the quality of incoming freshmen is a strong predictor of the ultimate success of a program's graduates on each section of the Uniform CPA exam, including the BEC component. Furthermore, students performing well on the predominantly objective ACT test might also be expected to be good test takers for the subsequent and predominantly objective CPA Exam.

Of the variables representing the five study components for the Business Environment and Concepts section, only the variables representing Cost and Finance coursework achieved significance. The coefficient in the Cost variable was significant at the 0.05 level and it was positive, as expected, indicating that more units of Cost within the accounting curriculum were associated with higher pass rates. At a level of .10, the coefficients on the finance variable and the AACSB variable were not significant at the standard level. The coefficient on the Finance variable was negative, suggesting the counter-intuitive idea that additional study in finance is associated with lower exam scores on the BEC section. The PRI/PUB variable was negative, but not significant.

Table 1

Regression of Business Environment and Concepts (BEC) Pass Rates

\begin{tabular}{|c|c|c|}
\hline \multicolumn{3}{|c|}{$\begin{array}{c}\text { Model: } \mathrm{BEC}=\beta_{0}+\beta_{1} \mathrm{BLW}+\beta_{2} \text { Econ }+\beta_{3} \text { Fin }+\beta_{4} \mathrm{IT}+\beta_{5} \text { Cost }+\beta_{6} \mathrm{ACT}+\beta_{7} \mathrm{AACSB}+ \\
\beta_{8} \mathrm{PRI} / \mathrm{PUB}+\epsilon \\
\mathrm{N}=190 \\
\mathrm{~F}=4.081^{* * * *} \\
\mathrm{R}^{2}=0.153\end{array}$} \\
\hline Constant & $\beta_{0}=$ & $\begin{array}{l}-33.894 * * \\
(-1.773)\end{array}$ \\
\hline BLW & $\beta_{1}=$ & $\begin{array}{l}-0.938 \\
(-0.974)\end{array}$ \\
\hline Econ & $\beta_{2}=$ & $\begin{array}{l}0.412 \\
(0.551)\end{array}$ \\
\hline Fin & $\beta_{3}=$ & $\begin{array}{l}-2.333^{*} \\
(-2.041)\end{array}$ \\
\hline IT & $\beta_{4}=$ & $\begin{array}{l}-0.305 \\
(-2.041)\end{array}$ \\
\hline Cost & $B_{5}=$ & $\begin{array}{l}2.250 * * \\
(2.261)\end{array}$ \\
\hline $\mathrm{ACT}$ & $\beta_{6}=$ & $\begin{array}{l}3.149 * * * * \\
(4.355)\end{array}$ \\
\hline AACSB & $B_{7}=$ & $\begin{array}{l}0.220^{*} \\
(0.052)\end{array}$ \\
\hline PRI/PUB & $B_{8}=$ & $\begin{array}{l}-7.483 \\
(-1.838)\end{array}$ \\
\hline $\begin{array}{l}* \text { Signific } \\
* * \text { Signifi } \\
* * * \text { Signif } \\
* * * * \text { Sign }\end{array}$ & & \\
\hline
\end{tabular}


As it appeared there may be a relationship between the Cost and Finance variable, another variable, C-F was calculated as the number of units of Cost courses in the curriculum less the number of units of Finance in the curriculum. The descriptive statistics for all previous variables plus this one appear in Table 2 on the following page.

Only Cost and Finance, of the topic areas, appeared to be associated with the pass rate in the presence of all the variables. In addition, there appeared to be a relationship between the amount of Cost and the amount of Finance courses in terms of outcomes on the BEC section of the CPA exam.

To further understand influences on the pass rate of the schools' graduates on the BEC exam, the Cost and Finance variables were replaced with a combined variable constructed as Cost units less Finance units in the curriculum. This new variable was tested, along with the remaining six original variables, in a stepwise regression model

The stepwise regression yielded a significant model using just three variables: ACT scores, Cost-Finance units of study and the private/public indicator. The coefficient on the Cost minus Finance variable was positive and significant to the .01 level suggesting that cost and managerial accounting courses indeed prepare students better for the CPA exam than finance courses which may cover similar material with better outcomes associated with a greater reliance on managerial accounting courses. The final results of the stepwise regression appear in Table 3 , also on the following page.

Table 2

Descriptive Statistics for Regression Variables

\begin{tabular}{|c|c|c|c|c|}
\hline \multicolumn{5}{|c|}{$\mathrm{N}=190$} \\
\hline Variable & $\underline{\text { Minimum Value }}$ & Maximum Value & Mean Value & $\underline{\text { Standard Deviation }}$ \\
\hline$\overline{\mathrm{BEC}}$ & $\overline{0}$ & $\overline{100}$ & $\overline{37.41}$ & 24.07 \\
\hline BLW & 0 & 9 & 3.74 & 1.79 \\
\hline Econ & 0 & 16 & 6.50 & 2.24 \\
\hline Fin & 0 & 9 & 3.25 & 1.50 \\
\hline IT & 0 & 12 & 4.39 & 3.01 \\
\hline Cost & 0 & 9 & 5.15 & 1.74 \\
\hline $\mathrm{ACT}$ & 16 & 31 & 23.31 & 2.48 \\
\hline AACSB & 0 & 1 & 0.49 & .501 \\
\hline PRI/PUB & 0 & 1 & 0.54 & .500 \\
\hline $\mathrm{C}-\mathrm{F}$ & -6 & 8 & 1.90 & 2.181 \\
\hline
\end{tabular}

Table 3

Stepwise Regression Results of Business Environment and Concepts (BEC) Pass Rates

$\begin{array}{lll} & & \text { Model: } \mathrm{BEC}=\beta_{0}+\beta_{1} \mathrm{ACT}+\beta_{2} \mathrm{C}-\mathrm{F}+\beta_{3} \text { PRI/PUB }+\epsilon \\ & \mathrm{N}=190 & \mathrm{~F}= \\ & & \mathrm{R}^{2}=0 . \\ & & -39.262^{* *} \\ \text { Constant } & (-2.496) \\ & \beta_{0}= & 3.254 * * * \\ \text { ACT } & \beta_{1}= & (4.776) \\ & & 2.324 * * * \\ \text { C-F } & \beta_{2}= & (3.102) \\ & & -6.673^{* *} \\ \text { PRI/PUB } & \beta_{3}= & (-1.976) \\ & & \end{array}$

* Significant at 1

** Significant at .05

$* * *$ Significant at .01

**** Significant at .001 


\section{CONCLUSION}

The significant finding of the positive impact of cost and managerial courses on success for the BEC section may be explained by the design of the exam itself. As detailed in the content specifications, the AICPA expects Planning and Measurement topics to comprise from twenty-two to twenty-eight percent of the Business Environment and Concepts section of the CPA exam (AICPA, 2003). Cost and managerial accounting courses cover most of the topics listed for this area. Additionally, the cost and managerial accounting courses often include more problem-solving critical thinking practice than other business and even accounting courses. This course is often the locus for case studies and, in contrast to many financial accounting problems, cost accounting problems often yield multiple solution approaches. Perhaps more cost and managerial study enhances students' abilities to address exam questions requiring higher level cognitive skills.

It is not surprising that the AACSB variable was not one of the three strongest predictors. So many business programs are actively involved in seeking or maintaining AACSB accreditation, that the fact of accreditation may not longer distinguish one school from another. The AACSB accreditation program may be achieving its goal of enhancing the quality of business education across the board.

The emergence of the PRI/PUB variable as a strong predictor does not lend itself to a pat explanation. The variable, while gaining significance in this model, retains its negative coefficient. The negative coefficient suggests that private schools, on average, are less likely to provide candidates that achieve high pass rate on the BEC exam. It should be remembered that private schools range from prestigious, well-endowed institutions to very small ones making a generalization difficult to sustain.

While many similarities are apparent across accounting programs, this study has demonstrated that differences in program structure may indeed be reflected in the ultimate performance of program graduates on the Business Environment and Concepts section of the CPA Exam. The study further suggests that cost and managerial accounting courses are valuable preparation for students of financial accounting. It may be useful to repeat this study when additional years of exam scores become available to determine whether this study's results are stable.

\section{AUTHOR INFORMATION}

David H. Lindsay, Ph.D., CPA (inactive), CISA, CFE is a Professor of Accounting and the Chair of the Department of Accounting and Finance at California State University, Stanislaus. His Bachelor of Arts is from Case Western Reserve University, his Masters of Business Administration is from The Cleveland State University, and his Ph.D. is from the Graduate School of Management at Kent State University. His research interests include: determinants of CPA Exam pass rates, the impact of merit programs on research and teaching outcomes, fraud detection, and various AACSB related issues. He teaches Intermediate Accounting I and II.

Annhenrie Campbell, PhD, CPA, CMA, CGFM is a Professor of Accounting at California State University, Stanislaus. She completed her MBA at Humboldt State University in California and her PhD at the University of Colorado in Boulder. After becoming a Certified Public Accountant and Certified Management Accountant, Dr. Campbell became a Certified Government Financial Manager at the start of the CGFM program. She maintains an active research and publication program and is involved in her students' professional preparation. She encourages students to maintain their professional currency with appropriate certifications and advanced study. She teaches advanced financial accounting and governmental accounting courses.

Kim Tan is an Associate Professor at California State University Stanislaus. Her Bachelor of Commerce and Administration degree is from Victoria University in Wellington, New Zealand; Master of Economics and Financial Studies from Macquarie University in Sydney, Australia; and $\mathrm{PhD}$ in Business Administration from Temple University in Philadelphia. She's a Chartered Accountant with the New Zealand Society of Accountants, and a member of the Australian Computer Society. She is interested in pedagogical and behavioral research using experimental, archival and survey data. She teaches Cost/Managerial Accounting, and is the founding co-faculty advisor of the Lambda Rho chapter of Beta Alpha Psi. 


\section{REFERENCES}

1. American Institute of Certified Public Accountants, Board of Examiners (2003). Business Environment and Concepts, Additional Detail Corresponding to Content Specification Outline dated June 14, 2002. Working paper dated October 10, 2003.

2. Al-Turki, U., \& S. Duffuaa. (2003). Performance measures for academia departments. The International Journal of Educational Management. 17(6/7):330-8.

3. Anonymous (2005). Looking Back, the Journal in 1917. Journal of Accountancy 199(5): 12.

4. Barron's (2007). Profiles of American Colleges, 2007 Edition, Hauppauge, NY.

5. Blum, J. (1994). Improved CPA Exam in 1994. Journal of Accountancy 172(4): 38-39.

6. Bragg, T. (1995). The Use of Occupational Licensure and Certification Examination Results as Performance Indicators. Journal of Applied Research in the Community College 2: 193-201.

7. California State University, Stanislaus. 2005-2006 Catalog. Appendix A.

8. DeMong, R.F., Lindgren, J.H., Jr., \& Perry, S. E. (1994). Designing an Assessment Program for Accounting. Issues in Accounting Education 9(1): 11-27.

9. Geiger, R.L. (1988). Public and private sectors in higher education: A comparison of international patterns. Higher Education 17(6): 699-711.

10. Levy, D.C. (1991). Accountability and Private-Public Comparisons. Educational Policy 5(2): $193-199$.

11. National Association of State Boards of Accountancy (2005). Candidate Performance on the Uniform CPA Examination: Reports and Commentary on the 2004 CPA Examination, NASBA, Nashville, TN.

12. Nelson, I.T. (1995). What's New About Accounting Education change? Accounting Horizons 9(4): $62-75$.

13. Rimerman, T.W., \& Solomon, J. P. (1991). Uniformity of Regulation -- The Time is Now. Journal of Accountancy 171(4): 69-72.

14. Rudnick, M., \& Taylor, V. (2006). How to Prepare Students for the new Economics and Finance Component of the CPA Exam. Journal of the American Academy of Business, Cambridge 9(2): 344-9.

15. Snyder, A. (2004). Tips on Preparing Employees for the New CPA Exam. Journal of Accountancy 197(3): 11-12.

16. Vangermeersch, R.G., \& Mackey, J. (2003). Failure of the New 'Business Environment and Concepts.' The CPA Journal 73(7): 58. 
NOTES 